\title{
Recenzja książki: Adam Mrozowicki, Jan Czarzasty (red.), 2020. Oswajanie niepewności. Studia społeczno- ekonomiczne nad młodymi pracownikami sprekaryzowanymi, Warszawa: Wydawnictwo Naukowe Scholar
}

\section{Streszczenie}

Artykuł jest recenzją książki Oswajanie niepewności. Studia społeczno-ekonomiczne nad młodymi pracownikami sprekaryzowanymi (2020) pod redakcją Adama Mrozowickiego i Jana Czarzastego. Autor omawia zawartość książki oraz komentuje wyniki badania i sposób ich przedstawienia.

Słowa kluczowe: atypowe zatrudnienie, badania biograficzne, prekarność, prekaryjność Kody klasyfikacji JEL: I31, I32, J60, J81, Z13

1 Akademia Sztuk Pięknych w Warszawie, Wydział Zarządzania Kulturą Wizualną, e-mail: piotr. plucienniczak@asp.waw.pl, https://orcid.org/0000-0003-4814-695X 
Book review: Adam Mrozowicki, Jan Czarzasty (Eds.) (2020). Oswajanie niepewności. Studia społeczno-ekonomiczne nad mtodymi pracownikami sprekaryzowanymi (Taming uncertainty: Socio-economic studies on young precarized workers). Warszawa: Wydawnictwo Naukowe Scholar

\begin{abstract}
The article is a review of the book titled Oswajanie niepewności. Studia społeczno-ekonomiczne nad młodymi pracownikami sprekaryzowanymi (2020), edited by Adam Mrozowicki and Jan Czarzasty. The author describes the content of the book, comments on the results, and provides his review.
\end{abstract}

Keywords: atypical employment, biographical research, precarity, precariousness JEL Classification Codes: I31, I32, J60, J81, Z13

Oswajanie niepewności pod redakcją Adama Mrozowickiego i Jana Czarzastego to pierwsze tak wszechstronne opracowanie doświadczenia prekarności w Polsce. Książka przedstawia przegląd wyników szeroko zakrojonego polsko-niemieckiego projektu badawczego PREWORK („Młodzi pracownicy prekaryjni w Polsce i Niemczech: socjologiczne studium porównawcze warunków pracy i życia, świadomości społecznej i aktywności obywatelskiej”). Autorzy antologii skupiają się na osobach młodych, dla których niskopłatna i niepewna praca jest codziennym doświadczeniem na rynku pracy - bo nigdy nie pracowały w inny sposób.

Temat nie jest całkiem nowy, w polskiej debacie publicznej i refleksji społecznej jest obecny od dekady. Tym, co wyróżnia PREWORK od dotychczasowych ujęć problemu, jest syntetyczne podejście do problemu prekarności: jako doświadczenia związanego nie tylko z rynkiem pracy, ale z całością egzystencji. Subiektywne poczucie niepewności ma źródło w pracy, ale wpływa na wszystkie sfery życia.

Książka składa się z trzech części: stustronicowego wstępu teoretyczno-metodologicznego, głównej części empirycznej oraz wyników porównawczych badań polsko-niemieckich, zawierających siedemnaście rozdziałów.

W pierwszej części (rozdziały 1-4) autorzy i autorki przedstawiają niezwykle bogate tło teoretyczne swojego badania. Prekaryzację pracy analizują w relacji do świadomości społecznej, strategii życiowych, indywidualnych zasobów, mentalności ekonomicznej, kultury i wartości ekonomicznych, wizji gospodarki dobrze urządzonej. Autorzy nie poprzestają na opisaniu własnych badań. Jeden z rozdziałów streszcza historię badań nad światopoglądem gospodarczym, a inny podsumowuje kolejne 
fale uelastyczniania rynku pracy w Polsce. Zaplecze teoretyczne i metodologiczne książki zostało świetnie przygotowane.

Druga, zasadnicza część, to seria rozdziałów (5-13) poświęconych różnym aspektom niepewnego życia. Znajdziemy tu artykuły na temat doświadczenia pracy, wchodzenia w dorosłość, czasu wolnego poza pracą, cierpienia, przedsiębiorczości, płci społeczno-kulturowej, migracji, zaangażowania w politykę oraz absencji wyborczej. Jest to część bardzo zróżnicowana i trudno ją podsumować. Satysfakcja z lektury zależy tu przede wszystkim od naszych zainteresowań badawczych - ale nie tylko, o czym dalej.

Trzecia, ostatnia część (rozdziały 14-17) podsumowuje międzynarodowy wymiar badań. Autorzy omawiają odmienne wizje gospodarki dobrze urządzonej oraz doświadczenia prekaryzacji młodych pracowników z Polski i z Niemiec. Ostatni rozdział stanowi typologia strategii życiowych podejmowanych przez badanych stworzona na podstawie wszystkich 123 wywiadów biograficznych przeprowadzonych w ramach projektu. Jest to, w mojej opinii, kluczowy rozdział książki, który przekształca ogrom informacji z biografii prekariuszy w potężne narzędzie analityczne.

Redaktorzy stawiają przed sobą cel ujednolicenia nomenklatury związanej z niepewnym życiem. To potrzebne i ważne zadanie. Prekarność, prekaryjność, prekaryzacja, prekariat - wszystkie te podobnie brzmiące słowa różnią się subtelnie zakresami znaczeniowymi. Prekarność to kruchość życia, prekaryjność to sytuacja odebrania danej populacji bezpieczeństwa. Prekaryzacja natomiast to proces rozszerzania tego braku bezpieczeństwa poprzez znoszenie instytucji ochronnych, takich jak bezterminowa umowa o pracę, dostęp do bezpłatnej ochrony zdrowia oraz ubezpieczenie społeczne. Osobnym fenomenem jest prekariat, czyli potencjalny ruch społeczny, który mógłby się wytworzyć na bazie podzielanych warunków pracy i życia młodego pokolenia. Szanse na jego powstanie autorzy książki oceniają jednak nisko.

Bardzo interesującą propozycją teoretyczną jest rozszerzenie kategorii zasobów, jakimi dysponują jednostki. Autorzy wychodzą tu od teorii Pierre’a Bourdieu, która wyróżnia zasoby (kapitały) ekonomiczne, kulturowe, społeczne oraz syntetyczny kapitał symboliczny. Listę tę uzupełniają o zasoby biograficzne, czyli pulę doświadczeń, które pozwalają radzić sobie z przeciwnościami losu, oraz zasoby emocjonalne, czyli zdolność odczuwania, tworzenia więzi oraz zarządzania życiem. Chodzi o to, by wzbogacić analizę zmagań z niepewnością: patrzeć na nią nie tylko przez pryzmat wykształcenia, pieniędzy czy kontaktów, ale także indywidualnej wiedzy i wypracowanych (niekoniecznie skutecznych) sposobów radzenia sobie z trudnościami. Włączenie współczynnika humanistycznego, czyli sensów i znaczeń, do studiowania trudnej problematyki, a badanej często z dystansem, ilościowo, to świetna decyzja badawcza. Wprowadzenie tych dodatkowych kapitałów pozwala na znalezienie 
w danych strategii życiowych, które związane są, na przykład, z doświadczeniem emigracji bądź mobilności międzyklasowej.

Zarzut, jaki mam do książki, to niedostatek wielowymiarowego podejścia do problemu prekarności. Idea intersekcjonalności, czyli współistnienia różnych form wykluczenia, pojawia się dopiero pod koniec książki, w rozdziale streszczającym wyniki badań niemieckiej części zespołu. To zaskakujące w publikacji, która tak wszechstronnie omawia problem prekaryjności. Podzielenie materiału na niewielkie i wyraźnie zakrojone tematycznie części („prekaryjność a płeć”, „....a przedsiębiorczość”, „... zaangażowanie polityczne”, „... a migracja” itd.) sprawia, że tracimy z pola widzenia złożoność doświadczenia niepewności. Jest ono podane w postaci wąskich próbek podporządkowanych logice socjologicznych subdyscyplin.

Dla przykładu: tylko jeden krótki rozdział poświęcono płciowym odrębnościom $\mathrm{w}$ doświadczaniu niepewności oraz wynikającym $\mathrm{z}$ tego różnicom $\mathrm{w}$ radzeniu sobie z niepewnością. Płeć społeczno-kulturowa warunkuje sposoby postępowania w razie odczuwania negatywnych emocji, sposoby nawiązywania i podtrzymywana więzi, ale także stosunek do edukacji i pracy. Kulturowo określone role płciowe skłaniają do podejmowania zajęć uważanych za „męskie” bądź „kobiece”, odpowiednich dla siebie. W gospodarce opartej na usługach większe szanse na stabilizację dają "miękkie" umiejętności i współpraca, co oznacza kłopoty dla mężczyzn (zwłaszcza z klasy robotniczej) przywiązanych do „twardej” pracy fizycznej i swoistego indywidualizmu. Płeć nie jest czynnikiem, który możemy wyabstrahować z badań strategii życiowych, oddzielić od warunków gospodarczych czy pochodzenia społecznego.

Próbkowanie materiału badawczego sprawia, że tracimy na rozumieniu prekaryjności jako wykluczenia, które wzmacnia się bądź osłabia w relacji do innych elementów biografii. Podejście holistyczne otwiera nowe pytania, które w książce są wzmiankowane, lecz nieanalizowane, np. związek między prekaryjnością a zdrowiem psychicznym. Jakie czynniki wpływają na wybieranie przez badanych strategii? Czy te wybory rozkładają się równo w badanej populacji? Oczywiście, że nie. Interesowałoby mnie omówienie wyników badania przez pryzmat zaprezentowanych w ostatnim rozdziale strategii, które współzależne są z bardzo różnymi czynnikami: pochodzeniem geograficznym i klasowym, etnicznością, płcią, światopoglądem i poglądami politycznymi, stanem zdrowia, sieciami społecznymi, wreszcie zasobami biograficznymi i emocjonalnymi. Pozostaje poczekać na zapowiadane kolejne publikacje, które będą pogłębiać wyniki tego ogromnego badania.

Niestety, nie wszystkie rozdziały książki utrzymują równie wysoki poziom analizy. Niekiedy odnosi się wrażenie pobieżności, gdy za ilustrację jakiejś tezy służy jedna wypowiedź respondenta (większość tekstów z części drugiej opiera się na analizie dwóch skontrastowanych wywiadów). Jest to specyfika badań biograficznych, 
które nie posługują się dużymi próbami. Z drugiej jednak strony, w trakcie badań przeprowadzono łącznie 123 wywiady (z czego $63 \mathrm{w}$ Polsce), co stanowi pokaźny materiał badawczy. Taki, który pozwala na bardziej szczegółowe analizy. Rozdział 13 (dot. przyczyn absencji wyborczej) opiera się na badaniach zewnętrznych wobec projektu PREWORK i stanowi mało reprezentatywne uzupełnienie głównych danych.

Kluczowy wskaźnik prekaryjnego zatrudnienia to niski dochód społeczny, który idzie w parze z formalną niestabilnością zatrudnienia. Każdy z autorów na początku swojego rozdziału pokrótce definiuje problem na użytek swój i swojej subdyscypliny. Zakładam, że te definicje są spójne, ale powtarzające się reformułowanie podstawowych pojęć jest nieco konfundujące dla osoby czytającej książkę rozdział po rozdziale.

Wymienione wady są pochodną przyjęcia takiej, a nie innej formy publikacji. Redaktorzy rozpoznają zresztą ten problem w zakończeniu, gdy przyznają, że książka stanowi jedynie wycinek i ilustrację głównych ustaleń. Czytelnicy mający oczekiwania co do publikacji sprecyzowane własną subdyscypliną mogą być z niej zadowoleni bardziej niż ja. Rozwinięcie postawionych w książce tez znajdzie się w kolejnych, zapowiadanych już publikacjach.

Oswajanie niepewności to niezastąpione wprowadzenie w życie młodych osób naznaczonych przez niepewną, krótkoterminową pracę. Jest to wgląd w życie kolejnego pokolenia ofiar modelu gospodarczego przyjętego w czasie transformacji ustrojowej. Różnorodne podejścia zaaplikowane do problemu otwierają nowe poznawcze perspektywy. Zachęcają przy tym do zadawania nowych pytań o konsekwencje normalizacji prekaryjnego zatrudnienia dla bardzo różnych sfer życia: od indywidualnego zdrowia psychicznego przez funkcjonowanie instytucji po stabilność systemu politycznego i gospodarczego.

Unless stated otherwise, all the materials are available under 